Article

\title{
Impact of Rural Land Transfer on Land Use Functions in Western China's Guyuan Based on a Multi-Level Stakeholder Assessment Framework
}

\author{
Zhichao Xue ${ }^{1}$ and Lin Zhen ${ }^{2, *}$ \\ 1 Institute of Geographic Sciences and Natural Resources Research, Chinese Academy of Sciences, \\ Beijing 100101, China; xuezc.14s@igsnrr.ac.cn \\ 2 School of Resource and Environment, University of Chinese Academy of Sciences, Beijing 100049, China \\ * Correspondence: zhenl@igsnrr.ac.cn; Tel.: +86-10-6488-8155
}

Received: 10 April 2018; Accepted: 26 April 2018; Published: 28 April 2018

check for updates

\begin{abstract}
To achieve sustainable rural development, it is necessary to simultaneously protect ecologically important land and efficiently use existing agricultural land. Land use functions (LUFs) are widely used to assess regional sustainable development. Guyuan is located in a typical hilly and gully region of western China, with ecologically fragile land. Rural land transfer (RLT) has been advocated to prevent abandonment of agricultural land and promote rational, effective utilization of the land. In this study, we used LUFs in a multi-level stakeholder assessment framework to integrate the opinions of all stakeholders in an evaluation of the impact of RLT on regional sustainable development. We employed the framework for participatory impact assessment, key informant interviews, and questionnaires to obtain data to support the development of scenarios to compare the impacts on LUFs. We found that RLT had positive impacts on each LUF in Guyuan, especially for the land-based production and food security LUFs. Importantly, the measures required to support RLT must vary among landforms and location conditions to successfully develop the LUFs and ensure sustainable development. We found that the integrated multi-level stakeholder assessment framework can comprehensively assess the impacts of land use measures on sustainable development and support regional land-use decision-making.
\end{abstract}

Keywords: land usage rights; land use functions; FoPIA; Guyuan; western China

\section{Introduction}

The approaches being used to support the use, management, and evaluation of land resources are changing rapidly [1-3]. This has been driven by growing recognition of the finite extent of fertile land, the insatiable demands of a growing human population, and rapid urbanization, along with recognition of the fragility of ecosystems [4,5]. It has therefore become necessary to balance conservation and protection of ecologically important land, such as forests and wetlands, with efficient use of the existing agricultural land [6-8]. However, estimates by Food and Agriculture Organization of the United Nations in 2011 indicated that up to $25 \%$ of all land worldwide is highly degraded, $36 \%$ is slightly or moderately degraded [9]. This condition threatens the sustainable land management at local, regional, as well as global level [10,11]. International organizations and institutions launched plans and regulations to call for global action to release the severe condition [12,13]. The Sustainable Development Goals (SDGs) released by UN in 2016 address highlights, in its 7 out of 17 goals, the importance of sustainable land use [14]. In line with this consideration, "Land Degradation Neutrality" is proposed by United Nations Convention to Combat Desertification (UNCCD) to contribute to the majority goals of the SDGs and deliver co-benefits for nearly all of them [11,15]. 
Therefore, to understand land use change impact on sustainability is currently a key issue for policy and scientific community [16,17]. The concept framework of Land Use Functions (LUFs) was developed by an interdisciplinary team within SENSOR - one of the sixth Framework Programme for Research launched by European Commission - to stress the need to evaluate land use changes impact on regional sustainability in a way that reflects the multiple dimensions inherent in the concept [18]. It has been widely used to assess regional sustainable development in Europe, China and some other developing countries [19-21]. LUFs refer to the goods and services provided by different land uses, and summarize the most relevant economic, environmental, and societal issues that a region faces [18,21]. The concept was extended to support solution-oriented research and policy development [22,23]. A healthy land use system not only has structural integrity, but also has functional continuity and additivity [24] (i.e., a system's structured functions provide more services than the simple sum of their individual values). Changes in land use or management systems result in complex interactions among LUFs.

At present, two factors are hampering the implementation of sustainable land management measures. First, policy developers often fail to gain the knowledge about the impacts of development before they design their policies on local sustainable development, and limited studies have addressed policy impact on regional sustainability or LUF $[25,26]$. For example, agricultural research and innovation under Horizon 2020 aims to support the Common Agricultural Policy to promote the sustainability and competition of the agriculture sector and rural areas, but has been hampered owing to the gaps between theory and practice [13]. Second, the process to implement sustainable land management measures tends to be inflexible and uniform, without considering necessary adjustments to account for unique regional or sectors conditions. Land systems are the result of human interactions with the natural environment [27], which contribute to numerous combinations of human activities and natural conditions. Land system science nowadays should focus on design sustainable transformations through stakeholder engagement $[27,28]$ and formulate recommendations for different target groups $[10,27,29]$. These issues are especially true in China, where land management measures are usually developed as a single approach to be applied in all regions, with the flexibility further constrained by disputes or a lack of coordination among government administrative divisions.

In China, the Chinese government has attempted to deal with widely distributed severe soil erosion and land degradation and to relieve the pressure on ecosystems by implementing a nationwide program since 1999, namely the Sloping Land Conversion Program (SLCP). Under this program, the government has attempted to convert cultivated land or barren land on steep slopes into grassland and forests, thereby protecting the land against soil erosion and further degradation. However, implementation of the SLCP has removed much agricultural land from production, thereby significantly decreasing grain production in many regions, especially in western China, the region that has the largest area of cultivated sloping land, and the grain loss was expected to reach $50 \%[30,31]$. Furthermore, with rising wages for non-agricultural work and an increasing number of aging workers on farms, abandonment of agricultural land is accelerating [32,33], thereby jeopardizing China's food security. In 2011 and 2013, 13.5\% and 15.0\% of China's agricultural land was idle [34]. Another serious problem is that the land which is not completely abandoned (i.e., set the land as their fundamental safeguard, or because of the need to feed themselves) is normally cultivated and managed by women and elderly family members [35]. Just as Bachelet stressed [36], women are the backbone of the development of rural and national economies. They comprise $43 \%$ of the world's agricultural labor force, which rises to $70 \%$ in some countries. It is a fact that rural women are the main contributors to food production. This is not, however, sufficient to meet future needs [36,37]. Increasing involvement of women and aged people in land cultivation practice in rural China is potentially a serious problem inhibiting further improvement in agricultural production $[35,38]$. Faced with these problems, the government has proposed a program of rural land transfer (RLT) to promote more rational and effective utilization of agricultural land and prevent agricultural abandonment $[39,40]$. 
RLT refers to the rural agricultural land use right circulation (i.e., change) in China. It was proposed in the 1980s to mitigate the inefficiency of decentralized land operation, and has evolved over time from individual and irregular land management to regional and organized management (Table 1). Under RLT, people who accept responsibility to manage land must do so under collective ownership of the land (i.e., the land is still owned by the government, but the agent of land management is changed under contract) and must not change the land use away from agriculture. If they meet these conditions, they can subcontract, lease, exchange, or otherwise to circulate the land usage right [41,42]. The process is voluntary rather than imposed. RLT does a good job of meeting the requirements of modernized agriculture, as it is market-oriented, large-scale, mechanized, and information-based. However, while promoting the RLT in a region, little attention has been paid to the influence of this program on land use and regional sustainable development.

Table 1. Evolution of the rural land transfer programs in China.

\begin{tabular}{clll}
\hline \multicolumn{1}{c}{ I: Spontaneous } & \multicolumn{1}{c}{ II: Exploratory } & \multicolumn{1}{c}{ III: Standardized } \\
\hline Period & \multicolumn{1}{c}{ 1980s } & Late 1980s to the 21st Century & Since the 21st Century \\
\hline \multirow{2}{*}{ Region } & $\begin{array}{l}\text { Coastal regions and the areas } \\
\text { surrounding large cities }\end{array}$ & $\begin{array}{l}\text { Expansion to central and } \\
\text { western China }\end{array}$ & Across the country \\
& $\begin{array}{l}\text { Land contracts awarded to } \\
\text { households, } \\
\text { Individual consultation and } \\
\text { collective adjustment }\end{array}$ & $\begin{array}{l}\text { Spontaneous transfers of land, } \\
\text { Transfers of land organized by } \\
\text { village committee }\end{array}$ & $\begin{array}{l}\text { Development of large farm } \\
\text { households, } \\
\text { Development of agricultural } \\
\text { enterprises, } \\
\text { Collective management }\end{array}$ \\
\hline $\begin{array}{l}\text { Main } \\
\text { regulations }\end{array}$ & $\begin{array}{l}\text { Household } \\
\text { responsibility system }\end{array}$ & $\begin{array}{l}\text { A system of contracting } \\
\text { separately for } \\
\text { grain-production fields (take } \\
\text { agricultural tax) and } \\
\text { responsibility fields (take } \\
\text { agricultural and contract fee) }\end{array}$ & $\begin{array}{l}\text { Abolishment of the } \\
\text { agricultural tax, }\end{array}$ \\
\end{tabular}

The Framework for Participatory Impact Assessment (FoPIA) is one popular sustainability assessment method that uses both qualitative knowledge (provided by stakeholders) and quantitative information (obtained by researchers or governments). It employs LUF criteria and encourages participatory policy development and planning. FoPIA is structured around the driver-pressure-state-impact-response framework [43], and can be applied to assess the impacts of a land-use policy $[20,44]$. FoPIA explores alternative scenarios at the relevant scales, assesses indicators that are assigned to LUFs, and encourages stakeholder participation throughout the planning and implementation process [45]. Nevertheless, to ensure a successful sustainability assessment, FoPIA should encourage the participation of experts from many backgrounds and fields of study [46]. Unfortunately, farmers and other residents of program areas are often excluded from FoPIA because of their lower education levels, even though they are responsible for most of the land management. This exclusion can result in incorrect assessments or one-sided results that fail to account for all factors that are important in a given region [47]. This is an important problem, because stakeholders with different social and geographical environments would have different knowledge and awareness of local opportunities and constraints, and hold different ideas and requirements when faced with the same management issue. Assessment measures must therefore strive to include as many stakeholders as possible to provide a complete picture of the management situation.

In the present study, we used Guyuan in western China as an example and applied a multi-level stakeholder assessment framework to assess the impact of the RLT program on LUFs in Guyuan. The research questions include: is the RLT suitable for Guyuan's sustainable development? What are the stakeholders' perceptions of the impact of implementing RLT on local development? What should be stressed and taken into consideration while implementing the RLT? The objectives of this 
research are to (1) formulate a multi-level stakeholder assessment framework to integrate the opinions of all stakeholders, in order to comprehensively assessing the impact of land use measures on local development; (2) evaluate the impact of RLT on regional sustainable development by using this framework, and through developing reference scenarios; (3) compare the perspectives of different groups of stakeholders and find out whether the adjustment is needed for different sub-regions while promoting the RLT. Our results provide both methodological and practical insights that will support the development of appropriate LUF policy in this region, while building the region's ecological, social and agricultural capacity by promoting sustainable land management.

\section{Materials and Methods}

\subsection{Study Area}

Located in the hilly and gully region of the Loess Plateau (Figure 1), Guyuan is an environmentally fragile and economically underdeveloped area of China. It has a semi-arid continental monsoon climate. The annual precipitation is limited and highly spatially and temporally variable. Based on the meteorological data and land cover and land change data provided by the Data Center for Resources and Environmental Sciences, Chinese Academy of Sciences (http:/ / www.resdc.cn/), the mean annual rainfall ranges from $431.4 \pm 197.9 \mathrm{~mm}$ in 2005 to $463.9 \pm 150.8 \mathrm{~mm}$ in 2015 [48], which is not sufficient to support rainfed farming. The main land use types are cultivated land $(44.7 \%$ of the total land use) and grassland (44.9\% of the total). Around $41.6 \%$ of the total area has a slope greater than $15^{\circ}$, and $12.1 \%$ has a slope greater than $25^{\circ}$, which makes cultivation difficult and makes the fine-grained loess soils highly vulnerable to erosion. The major crops are winter wheat in rotation with summer maize and potato, which account for $48.0 \%$ of the total cultivated area. The agricultural population is 1.11 million, and these workers account for $74.4 \%$ of the total population. However, the disposable income of rural households is 7002.1 CNY, which is lower than the provincial average of 9119.0 CNY and the national average of 11,422.0 CNY in 2015 [49]. The approximate conversion rate in 2015 was about 6.4 CNY per U.S. dollar.

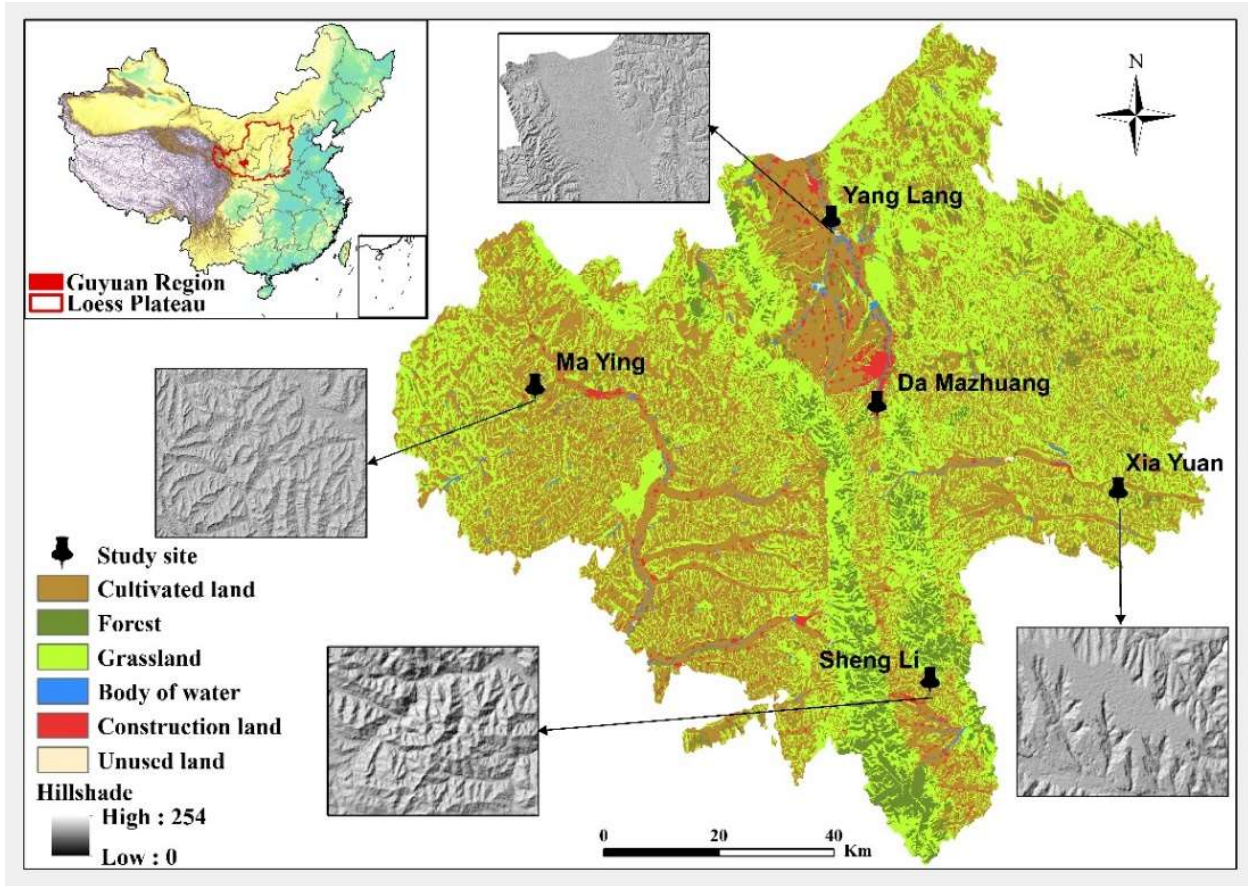

Figure 1. Location of Guyuan and of the study sites, and the associated topography and land uses. 
Since implementation of the SLCP in 2000, Guyuan has increased the area of forest and grassland by $3.11 \times 10^{5}$ ha, of which $1.69 \times 10^{5}$ ha was provided by conversion of cultivated land, which accounted for $44.9 \%$ of the total crop area $\left(3.76 \times 10^{5} \mathrm{ha}\right)$ in 2015 [48,50]. However, younger residents of Guyuan have increasingly been leaving agriculture in search of jobs that provide a better income, leading to aging of the agricultural workforce. Although the SLCP has restored vegetation in a large amount of the abandoned arable land $\left(1.41 \times 10^{5} \mathrm{ha}\right)$, local experts report that nearly $25 \%$ of the land remains abandoned.

The abandoned agricultural land significantly threatens local food security [51-53]. In addition, because nearly half of the cultivated land is on steep slopes with fine-grained loess soils, the abandoned land is highly vulnerable to erosion, and its variable distribution has led to problems related to land use fragmentation historically [54]. Local experts told us that RLT, which could consolidate small fields into larger areas to improve the efficiency of management, would simultaneously improve the usage of abandoned land and the economic development, as it has done in successful implementations in other parts of China [39]. In Guyuan, the primary land use type in rural areas is cultivated land, so RLT mainly refers to the exchange of usage rights for cultivated land or the transfer of cultivated land among households, companies and communities. The current land transformation conditions in Guyuan can be summarized as follows [55]:

1. The scale of the transfers is increasing, but remains small. The total exchange of contracted cultivated land in 2008 was 6706.53 ha, versus $49,642.73$ ha in 2015, which represents only $13.2 \%$ of the total cultivated area.

2. The plant types on the transferred land have expanded from the original types (mainly crops) to tree seedlings produced for afforestation or trade, fruit trees, and cash crops. The area for food crops after the abovementioned exchanges was only $2.08 \times 10^{4}$ ha, accounting for $41.9 \%$ of total transferred area. This suggests that land exchanges have not well-supported the original goals of the RLT, which is to improve the production and efficiency of cultivated land.

3. The form of RLT is evolving from spontaneous private exchanges to more organized flows, but the regulations to support this evolution are insufficient. The transfer form in Guyuan mainly includes rentals, subcontracting and exchanges; the most popular form is rentals, which affected 38,165 ha ( $76.9 \%$ of the total transferred land). However, owing to the official statistic data by local government, the amount of land transferred under official contracts was 39,302 ha, accounting for $79.2 \%$ of the total transferred land. However, local experts stressed that the real contracts proportion would be even less with many individual transaction, suggesting the unsound of the transfer system.

4. The rental fees for transferred land vary widely owing to differences in the land conditions. The high-quality land rents for a higher price of around 33.3 CNY/ha annually, and annual rents can increase by $0.7 \mathrm{CNY} /$ ha annually. In contrast, the lowest price is $2 \mathrm{CNY} /$ ha annually for hilly and dry land. In 2017, to promote RLT, the government of Guyuan introduced shareholding systems, based on successful experiences elsewhere in China, to account for the dry climate and local conditions for labor mobility, with the goal of promoting land transfers.

5. The RLT is usually related to a single type of plant in a large area. These plants are typically cereals, vegetables, and wolfberry (Lycium chinense) in Guyuan, owing to that they are suitable for this region to improve earnings. For example, in Yang Lang village, the biggest household interviewed has rented 66.47 ha of land, which is nearly $13.8 \%$ of the entire village's crop area, and he chosen to plant only wolfberry and pumpkins in 2016. This condition has the potential to threaten the biodiversity and the maintenance of ecosystem processes [56]. 
In summary, the current conditions for transferring land use rights in Guyuan represent an exploratory stage, with many problems that still remain unsolved. Because the government officials are not sure yet about the local suitability of RLT and its future prospects. Thus, it is needed to make feasibility studies on RLT based on land location, geomorphology, quality and accessibility to water resources, in order to decide whether the land transfer is possible; at the same time, willingness and perceptions of the farmers on RLT need to be evaluated. Based on such studies, the politicians can further improve current policies and regulations related to land transformation.

Guyuan has wide variation in landforms. Based on suggestions from local experts (Specific information of these transdisciplinary experts can be found in Section 2.2.1 and the Supplemental Table S1), we selected four villages to represent plain land in the valley (Yang Lang), loess tableland (Xia Yuan), plateau hills (Ma Ying), and stony mountains (Sheng Li), and one village (Da Mazhuang) to represent a peri-urban village. This will let us compare the factors that constrain sustainable agricultural management in each region. The characteristics of the selected villages, as well as their locations, topography, and land uses can be found in Table 2 and Figure 1 respectively.

\subsection{Multi-Level Stakeholder Assessment Framework}

LUFs allow for a balanced classification of regional sustainability issues into economic, social, and environmental dimensions $[18,46]$. By identifying and defining the key set of LUFs and related assessment indicators, impact assessment would be conducted. With the core of LUFs, we developed a multi-level stakeholder assessment framework. The stakeholders in land use generally include two groups [57]: "decision makers" (e.g., government representatives) and "decision takers" (e.g., local farmers [58]). However, in China, village managers often control the public resources of the village and play a significant role in the life of its farmers. Therefore, we included them as stakeholders in our research, and refer to them as "management coordinators". Since different stakeholder groups had different interests, we used different approaches to survey each group, but with a shared overall objective: the impact of the RLT program on the LUFs. Our research team comprised both professors and young research fellows with expertise in land use and sustainable development.

We used the following methods for the stakeholder groups. First, we used interactive workshops (FoPIA) to survey government employees and local experts. We brought together a multidisciplinary team of experts (see the next section for details) to work with government employees in relevant departments, and organized the workshops to design a policy scenario (the RLT program), a control scenario, and a negative control scenario, and together, we assessed their impacts on LUFs in Guyuan. Second, we used key informant interviews for the "management coordinators" group. In this method, we conducted in-depth interviews to obtain information from community residents who were in a position to know the community as a whole, or the particular portion of the community involved in a specific land use in their village [59]. Third, we used questionnaires to obtain data from other villagers (the decision-takers). Because it was possible that not all farmers would accept this approach (e.g., some were illiterate) or understand technical concepts such as LUFs, we designed the questionnaire to describe the LUFs in terms they could understand. 
Table 2. Characteristics of the study villages and survey details.

\begin{tabular}{|c|c|c|c|c|c|c|c|}
\hline \multirow{2}{*}{ Village } & \multirow{2}{*}{ Feature } & \multirow{2}{*}{ Slope of Cultivated Land ${ }^{1}$} & \multirow{2}{*}{ Agricultural Land Abandonment } & \multirow{2}{*}{ Livelihood } & \multirow{2}{*}{ Questionnaires } & \multicolumn{2}{|c|}{ Key Informant Interviews } \\
\hline & & & & & & Village Managers & Farmer \\
\hline Yang Lang & Valley plain & $99.6 \%$ with slopes $<5^{\circ}$ & $\begin{array}{c}\text { Before RLT, } 14.3 \% \\
\text { After RLT, } 0 \% \\
\text { 85\% of farmland is irrigated; } \\
\text { other land abandoned mostly due } \\
\text { to drought }\end{array}$ & Mainly work in town & 49 & 2 & 1 \\
\hline Ma Ying & Plateau hills & $72.6 \%$ with slopes $>25^{\circ}$ & $\begin{array}{l}10 \% \text { but increasing, most land } \\
\text { difficult to access from farmer } \\
\text { homes; no participation in SLCP }\end{array}$ & $\begin{array}{c}\text { Mainly farming, } \\
\text { with part-time jobs in town }\end{array}$ & 33 & 2 & 1 \\
\hline Xia Yuan & Tableland and hills & $64.6 \%$ with slopes $<15^{\circ}$ & $\begin{array}{c}\text { Before SLCP, } 20.0 \% \text {. } \\
\text { After SLCP, } 14.3 \% \\
\text { mainly living and farming on } \\
\text { tableland; steepness and faraway } \\
\text { hill land would be abandoned }\end{array}$ & $\begin{array}{l}\text { Mainly farming and } \\
\text { livestock breeding, } \\
\text { with part-time jobs in town }\end{array}$ & 37 & 2 & 1 \\
\hline Sheng Li & Stony mountains & $65.8 \%$ with slopes $>15^{\circ}$ & $\begin{array}{c}\text { Before SLCP, } 13.3 \% \\
\text { After SLCP, } 0 \% \text { (replaced by tree } \\
\text { nurseries and the forest economy) }\end{array}$ & Mainly work in town & 40 & 2 & 1 \\
\hline Da Mazhuang & Peri-urban village & $62.4 \%$ with slopes $<5^{\circ}$ & $\begin{array}{l}\text { Before SLCP, } 50.0 \% \\
\text { After SLCP, } 15 \%\end{array}$ & $\begin{array}{c}\text { Mainly work in town } \\
\text { (convenient transportation) }\end{array}$ & 43 & 2 & 1 \\
\hline
\end{tabular}

${ }^{1}$ Statistical data from questionnaires. RLT: rural land transfer; SLCP: Sloping Land Conversion Program. 


\subsubsection{FoPIA to "Decision Makers"}

\section{(1) FoPIA framework}

We structured the FoPIA approach, as described by Morris et al. [26], into three phases: preparation (problem definition and choice of LUFs and indicators), participatory evaluation (definition of the context for the scenarios and impact assessment), and analysis of the results followed by preparation of recommendations (Figure 2). In the preparation phase, we held the first workshop and gathered experts from many disciplines (agriculture, hydrology and water resources, economic, regional planning, human resources and social security, forestry, environmental) to define and discuss the current land use problems, the causes and driving forces of these problems, and the implementation of relevant policies (scenarios). We described the main LUFs and associated assessment indicators in preparation for the next phase. In the participatory evaluation phase, we conducted a second workshop to initiate a discussion of the scenarios, the LUFs and their associated assessment indicators, and develop a paper-based assessment and each participant weighted the LUFs in terms of their importance and scored the indicators in each scenario in terms of the impacts, so that we could reach consensus on LUFs' relative importance and the scenarios impactions on LUFs. The final phase, in which we analyzed the results and prepared recommendations, started with a summary of the previous workshop results and final discussion of these results, followed by preparation of policy recommendations based on these results.

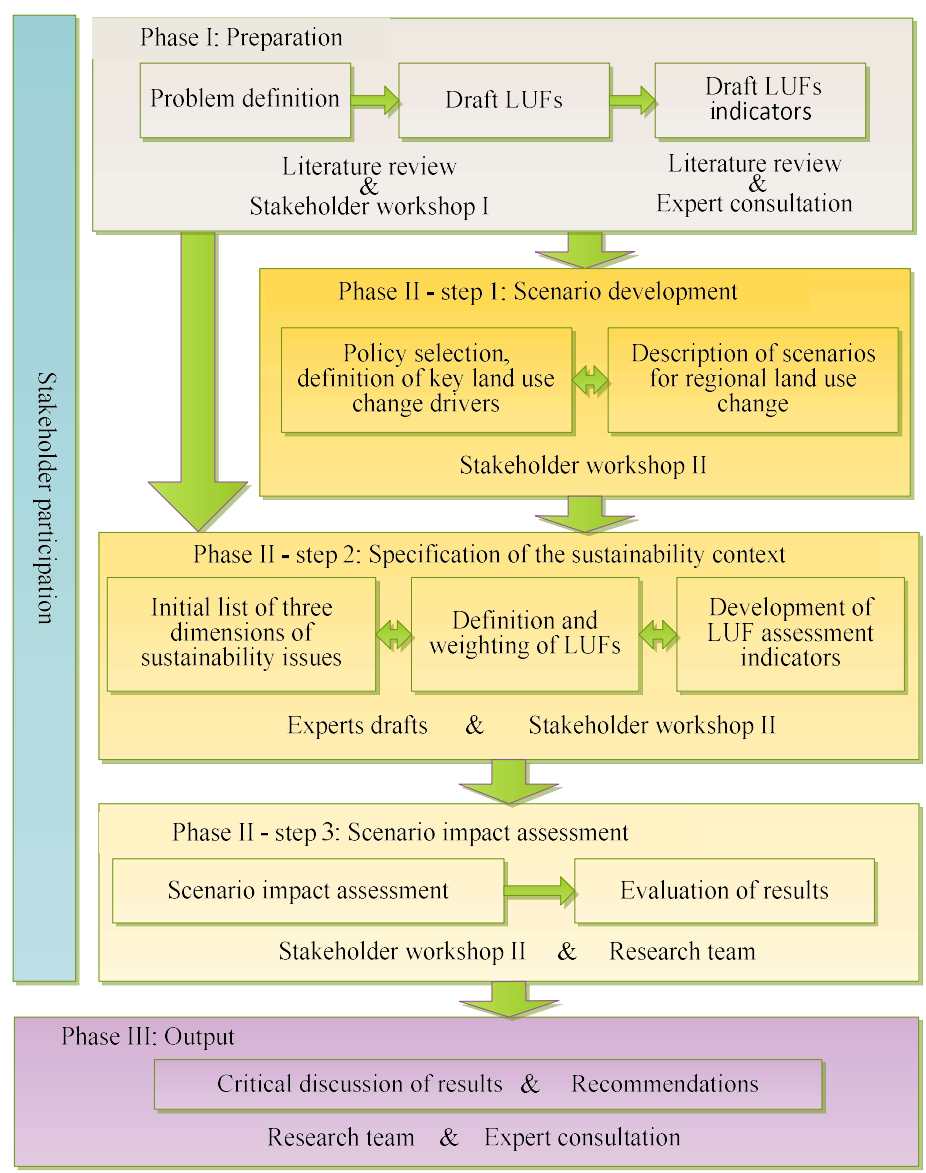

Figure 2. The framework used for participatory impact assessment to identify and assess the land use functions (LUFs). 
(2) Stakeholders involved in the FoPIA

The workshops were designed to include a manageable and effective number of experts [26]. We chose 10 participants with backgrounds in multiple economic, social, and ecological disciplines to provide comprehensive perceptions of land use issues $[20,60]$ related to land use management or policies. The first preparation workshop was conducted in September 2015; details are provided by Wang and Zhen [47]. We process the results of discussion by combining with the literature analysis, then conducted the second participatory workshop in May 2017, with five policy-makers and five researchers (two local university researchers; two researchers from the Institute of Geographic Sciences and Natural Resources Research, Chinese Academy of Sciences; and one researcher from the Chinese Academy for Environmental Planning). These individuals were experts on regional land use and the local participants had at least 9 years of work experience in this field (Supplemental Table S1).

(3) Scenario development

In China, governments formulate development plans on a 5-year cycle, so we chose a 10-year period (i.e., two planning cycles) as sufficient to allow implementation and assessment of a policy. The context for the scenarios therefore extended from 2015 to 2025. We focused on problems related to abandoned agricultural land and extensive (rather than intensive) land use on the remaining land, combined with the trial implementation of RLT in Guyuan. In this context, we proposed three scenarios in the phase II of FoPIA workshop:

1. RLT scenario: The experts believed that the RLT would be the most effective way to achieve the goals of increasing land use efficiency and dealing with abandonment of agricultural land. Thus, in this scenario, we assumed that the RLT would be promoted well, and that all abandoned land would be transferred and reused for agriculture, with the transfers matched to the irrigation and road infrastructures.

2. Business as usual (BAU) control scenario: This scenario assumed that land use efficiency and abandonment of agricultural land would continue to follow current trends, and that RLT would be spontaneous rather than carefully organized. According to local experts, this would likely lead to $30 \%$ of the agricultural land being abandoned and $20 \%$ of the land transferred by 2025 .

3. Agricultural land abandonment (ALA) negative control scenario: To reveal the future of agriculture land abandonment, we assumed that during the next 10 years, the trend to abandon cultivated land would accelerate, and that all land with inferior quality, land that was located on steep slopes, and land without easy access for residents would be abandoned. Households with insufficient labor would also abandon their lands. The experts suggested that at least $60 \%$ of agricultural land would be abandoned under this scenario.

(4) LUFs and associated assessment indicators

We defined the nine most important LUFs in Guyuan and the corresponding indicators in the second workshop in FoPIA. We divided these indicators into economic, social, and ecological dimensions (Table 3). The LUFs are the same in all three stakeholder evaluations. 
Table 3. Land use functions and indicators in Guyuan.

\begin{tabular}{|c|c|c|c|c|}
\hline Dimension & No. & Land Use Functions & Regional Relevance & Indicators \\
\hline \multirow[t]{3}{*}{ Economic } & 1 & $\begin{array}{l}\text { Residential or non-land-based activities: } \\
\text { Provision of space where residential, social } \\
\text { and productive human activity takes place }\end{array}$ & $\begin{array}{l}\text { Construction land, and especially } \\
\text { the residential land, to meet the } \\
\text { basic needs of farmers }\end{array}$ & $\begin{array}{l}\text { Percentage of } \\
\text { construction land }\end{array}$ \\
\hline & 2 & $\begin{array}{l}\text { Infrastructure: The quantity and quality of } \\
\text { roads as a means to connect rural regions } \\
\text { with other regions }\end{array}$ & $\begin{array}{l}\text { For remote rural areas, the road } \\
\text { infrastructure strongly influences } \\
\text { the potential for economic } \\
\text { development }\end{array}$ & $\begin{array}{l}\text { Density and quality } \\
\text { of the } \\
\text { transportation } \\
\text { network }\end{array}$ \\
\hline & 3 & $\begin{array}{l}\text { Land-based production: Provision of land } \\
\text { for economic production, including } \\
\text { agricultural and forest products }\end{array}$ & Provide a basic income for farmers & $\begin{array}{l}\text { Output value of } \\
\text { primary } \\
\text { agricultural and } \\
\text { forest industries }\end{array}$ \\
\hline \multirow[t]{3}{*}{ Social } & 4 & $\begin{array}{l}\text { Provision of work: Employment } \\
\text { opportunities for activities based on natural } \\
\text { resources }\end{array}$ & $\begin{array}{l}\text { Basic and traditional forms of } \\
\text { employment for farmers }\end{array}$ & $\begin{array}{l}\text { Proportion of } \\
\text { agricultural } \\
\text { employees }\end{array}$ \\
\hline & 5 & $\begin{array}{l}\text { Quality of life: A good living standard in } \\
\text { rural regions related to factors that should } \\
\text { improve the quality of life }\end{array}$ & $\begin{array}{l}\text { The satisfaction of farmers with } \\
\text { their land }\end{array}$ & $\begin{array}{l}\text { Per capita public } \\
\text { green space }\end{array}$ \\
\hline & 6 & $\begin{array}{l}\text { Food security: Access to and availability of } \\
\text { a sufficient quantity and quality of food }\end{array}$ & $\begin{array}{l}\text { Local farmers would not abandon } \\
\text { land because it was necessary to } \\
\text { ensure that they received a } \\
\text { sufficient quantity and quality of } \\
\text { food }\end{array}$ & $\begin{array}{l}\text { Per capita grain } \\
\text { output }\end{array}$ \\
\hline \multirow[t]{3}{*}{ Ecological } & 7 & $\begin{array}{l}\text { Provision of abiotic resources: The land's } \\
\text { role in regulating the supply and quality of } \\
\text { soil and water }\end{array}$ & $\begin{array}{l}\text { Water and soil are both essential in } \\
\text { this semi-arid area }\end{array}$ & $\begin{array}{l}\text { Per capita water } \\
\text { resources }\end{array}$ \\
\hline & 8 & $\begin{array}{l}\text { Provision of biotic resources: Provision of } \\
\text { habitat and biodiversity, and factors } \\
\text { affecting the capacity of the land to support } \\
\text { them in regions }\end{array}$ & $\begin{array}{l}\text { Vegetation cover and diversity } \\
\text { indicates an improved environment } \\
\text { in this semi-arid region }\end{array}$ & $\begin{array}{l}\text { Vegetation cover of } \\
\text { forests and grasses }\end{array}$ \\
\hline & 9 & $\begin{array}{l}\text { Maintenance of ecosystem processes: The } \\
\text { land's role in the regulation of ecosystem } \\
\text { processes, the regulation of natural } \\
\text { processes related to the hydrological cycle, } \\
\text { and ecological supporting functions such as } \\
\text { soil formation }\end{array}$ & $\begin{array}{l}\text { Undisturbed land is the basis for a } \\
\text { local environment-friendly life }\end{array}$ & Soil conservation \\
\hline
\end{tabular}

Source: Framework for Participatory Impact Assessment (FoPIA) workshop, 2017.

(5) Scenario impact assessment

We assessed the importance of the LUFs using a two-round assessment, in which participants assigned weights from 0 (not important) to 5 (extremely important) in the first round, then discussed and resolved any differences in the second round. If the stakeholders did not agree on any result, we used an additional round of discussion to seek consensus, and then, used the following equation to calculate the mean weight of each LUF:

$$
w_{i}=\frac{1}{n} \sum_{j=1}^{n} w_{i j}
$$

where $w_{i}$ is the weight of LUF $i(i=1$ to 9 ), $n$ is the total number of participants, $j$ is the $j$ th participant in this workshop, and $w_{i j}$ is the weight that expert provided for LUF $i$.

We then conducted a two-round assessment of the impacts of the three scenarios and possible trade-offs on the selected LUFs at a regional level, in which participants score the impacts of the scenarios to each LUF between -3 (most negative impacts) to 3 (most positive impacts) [26] in the first round, then discussed and resolved any differences in the second round. If the stakeholders did not agree on any result, an additional round is needed. We assessed the scenarios one by one and calculated the final score for each scenario using the following equation:

$$
f_{k i}=\frac{1}{n} \sum_{j=1}^{n} f_{k i j}
$$


where $f_{k i}$ is the score for LUF $i(i=1$ to 9$)$ in scenario $k(k=1$ to 3$)$, and $f_{k i j}$ is the last-round score for expert $j$.

We aggregated the impact assessment results (scores) for each LUF, for the three dimensions of sustainability (economic, social, ecological), and for synthetic using the following equations:

$$
\begin{gathered}
F_{k i}=w_{i} \times f_{k i}(k=1,2,3) \\
F_{k, d}=\left\{\begin{array}{l}
F_{k, e c o}=\sum_{i=1}^{3}\left(w_{i} \times f_{k i}\right),(k=1,2,3) \\
F_{k, s o c}=\sum_{i=4}^{6}\left(w_{i} \times f_{k i}\right),(k=1,2,3) \\
F_{k, e c g}=\sum_{i=7}^{9}\left(w_{i} \times f_{k i}\right),(k=1,2,3) \\
F_{k}=\sum_{i=1}^{9}\left(w_{i} \times f_{k i}\right),(k=1,2,3)
\end{array}\right.
\end{gathered}
$$

where $F_{k i}$ is the final assessment score for LUF $i(i=1$ to 9$)$ in scenario $k(k=1$ to 3$), F_{k, d}$ represent the assessment score by dimensions. $F_{k, e c o}, F_{k, s o c}, F_{k, e c g}$ is the final assessment scores for economic dimension, social dimension and ecological dimension in scenario $k(k=1$ to 3$)$, respectively. $F_{k}$ is the final assessment score for scenario $k(k=1$ to 3$)$. Using $F_{k}$ to compare the alternative scenarios, we ranked the scenarios to provide possible implications for land management and decision support for policy recommendations.

\subsubsection{Key Informant Interviews with Management Coordinators}

We interviewed the key informants (i.e., village managers) to obtain information on natural environmental conditions, the livelihoods of farmers, and the willingness of local farmers to continue farming in the future in each village. Our goal was to use this information as a reference for the assessment responses of the decision-maker and decision-taker groups. To choose these key respondents, we used the following principles:

1. The final group must contain at least one village manager and one farmer to represent the roles of leader and implementer in the village, and describe their different willingness for taking and supporting the decision-making exercise.

2. Village managers should have a minimum of 5 years of work experience, and had handled the overall operation of the village.

3. The farmers should have a minimum of 10 years of experience in the village, were familiar with village conditions, and were not young people with long-term work outside the village or housewives who only worked at home.

We developed a semi-structured interview process from 2 to 9 May 2017, with questions focused on the LUFs conditions in each village and three key informant interviews in each village. Interviews with village managers included questions about the land use changes that had occurred in the last 20 years and the possible abandonment or transformation trends in the future, as well as land use problems in the village and the willingness of farmers. We collected and extracted the background information through the statements of key informants, and used it as a fundamental basis for the analysis and explanation on the results of FoPIA and questionnaires.

\subsubsection{Questionnaire for Decision Takers}

The questionnaire was designed to obtain basic information on the respondent's family, the status of agricultural land abandonment and their willingness to abandon their land, and the willingness to attend the RLT program and opinions on RLT. The basic family data included the gender, age, main occupations, and education levels of members of the household. The second part asked about whether 
they had abandoned agricultural land and the reason. The last part asked about their experience with the RLT program, their willingness to transfer more land with the local government coordination, and the reasons for this willingness. Each questionnaire took around $50 \mathrm{~min}$ to finish.

We referred to the specific LUFs in each dimension that were defined during the FoPIA workshops, and we classified farmer understanding of the LUFs for the economic dimension of land usage (rents, land-based income, higher yields), the social dimension (employment, maintaining basic living conditions, and two kinds of income (i.e., income from farming and from rent) to improve the quality of life), and ecological dimension (more sustainable use of the land, land quality improvement, good for the environment). We normalized the impact assessments from the RLT program scenario in the FoPIA by calculating the percentage values of each dimensions $\left(F_{k, d}\right.$, where $k=1$, represent RLT scenario) in the synthetical value ( $F_{k}$, where $k=1$, represent RLT scenario), and we also normalized the questionnaire data from farmers by analyzing the percentage of farmers who mentioned the factors in each dimension. So that they would all in 0 to 1 , and represent the importance degree of LUFs dimensions in RLT for farmers and for experts, respectively. This let us compare the views of these two groups for the three dimensions.

We chose the sample households by random in each village, and decided the final sample size (number of households) based on the suggestions of the village managers, to ensure the reliable and representative. From 2 to 9 May 2017, we obtained answers to the questionnaire in each village by means of face to face interviews. We collected a total of 202 valid questionnaires.

\section{Results and Discussion}

\subsection{FoPIA-Based LUF Assessment}

\subsubsection{Weights of the LUFs}

The LUFs in the ecological dimension had the highest score, at an average of 4.00 (Figure 3). This shows recognition of the importance of the ecological environment and the effectiveness of the promotion and protection work that has been conducted in the past several years. For example, in Yuanzhou County, the forest cover has increased from $11.0 \%$ in 2009 to $14.0 \%$ in 2015, representing a $27.8 \%$ increase. The local government has also stressed the importance of these programs to maintain good environmental conditions. The economic dimension was rated second, with an average score of 3.83. Therefore, residents recognized the importance of factors that would let them earn a satisfactory living. Analysis of the specific economic functions showed that food security had the highest weight (4.50), followed by land-based production (4.33). Because $74.4 \%$ of Guyuan's population works in agriculture, the fundamental livelihood is farming, so the quality and quantity of the land's production were clearly important. The lowest score was for the social dimension, with an average score of 3.39. Of the specific functions, employment had the lowest score (2.50), possibly because more and more farmers would like to work in the city, and they therefore placed less value on the employment provided by their land. In addition, with the desire of farmers to move to the city to find off-farm jobs ("rural labor transfer"), the local government also has organized technical trainings to prepare farm workers for these new jobs and help them escape poverty. This program benefited 193,177 people from 2005 to 2015. Government statistics suggest that the number of rural workers who moved to cities increased from 180,000 people in 2003 to 308,800 in 2015 , a $71.6 \%$ increase that amounted to $27.7 \%$ of the total agricultural workers in 2015 . The income from this transferred employment accounted for $44.3 \%$ of the regional average per capita disposable income of farmers [61]. Thus, with the irresistible trend of rural labor transfer, the importance for employment functions of their land would be continuously decreasing. 


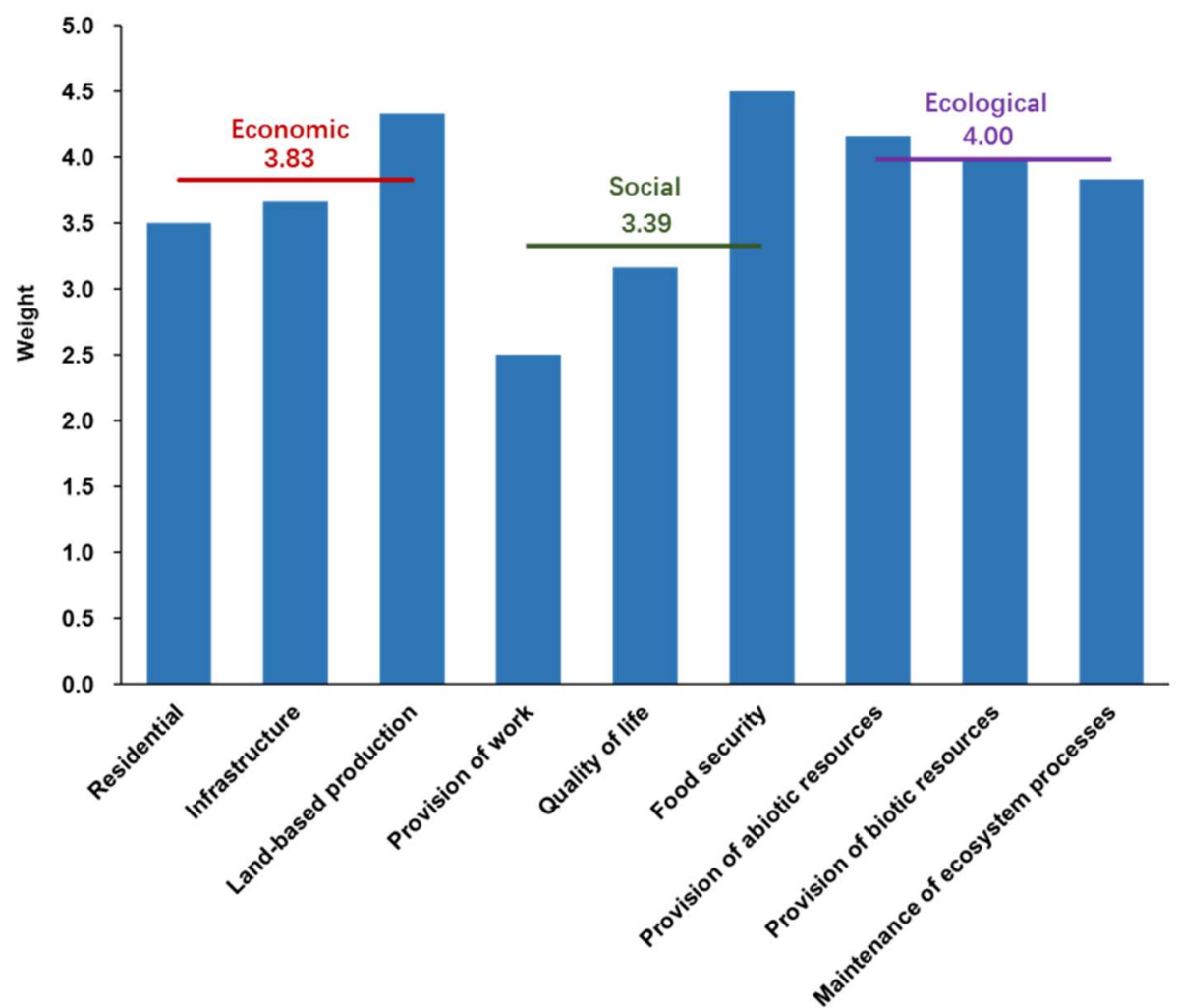

Figure 3. Land use functions in each of the three dimensions.

\subsubsection{Impact Assessment of the LUFs under the Three Scenarios}

When we synthesized the results, the order of impacts was RLT scenario (26.98) > BAU scenario (16.19) > ALA scenario (5.71). RLT earned the highest score, it reflected the superiority of this approach for achieving sustainable regional development. In terms of the three dimensions (Figure 4), RLT got the highest score in the economic and social dimensions, but the lowest score in the ecological dimension (2.79). In contrast, the ALA scenario earned the highest score in the ecological dimension, but the lowest score in the economic and social dimensions. The BAU scenario had intermediate values for all three dimensions.

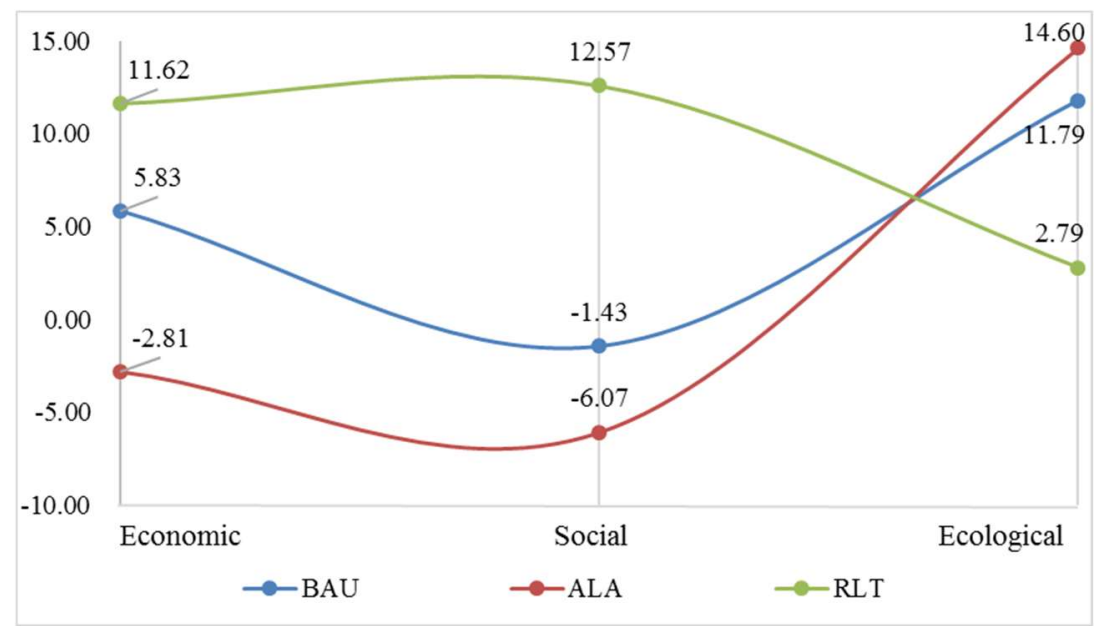

Figure 4. Impacts of the three scenarios on the land use functions' three dimensions (predicted values in 2025). Scenarios: ALA, agricultural land abandonment; BAU, business as usual; RLT, rural land transfer. 
Figure 5 synthesizes the impact assessment results and the key informant interview results to further clarify the details of our assessments. In the economic dimension, the most contributing function is land-based production, followed by infrastructure and residential. RLT could improve this function from negative under BAU and ALA to positive, with the most dramatic increase reaching $208.8 \%$ compared with ALA. This is because the transfer of cultivated land in the RLT program and start the concentrate using of cultivated land, and allocated with irrigation facility and machines by big farming households or companies who rent the land, would greatly improve the quality of the land, especially in the most arid areas. For example, in Yang Lang Village, implementation of RLT increased the proportion of irrigated land from $50.0 \%$ to $86.1 \%$, decreased the proportion of abandoned land from $13.9 \%$ to $4.0 \%$, and at least doubled the crop yield in irrigated land compared to that in rainfed fields.

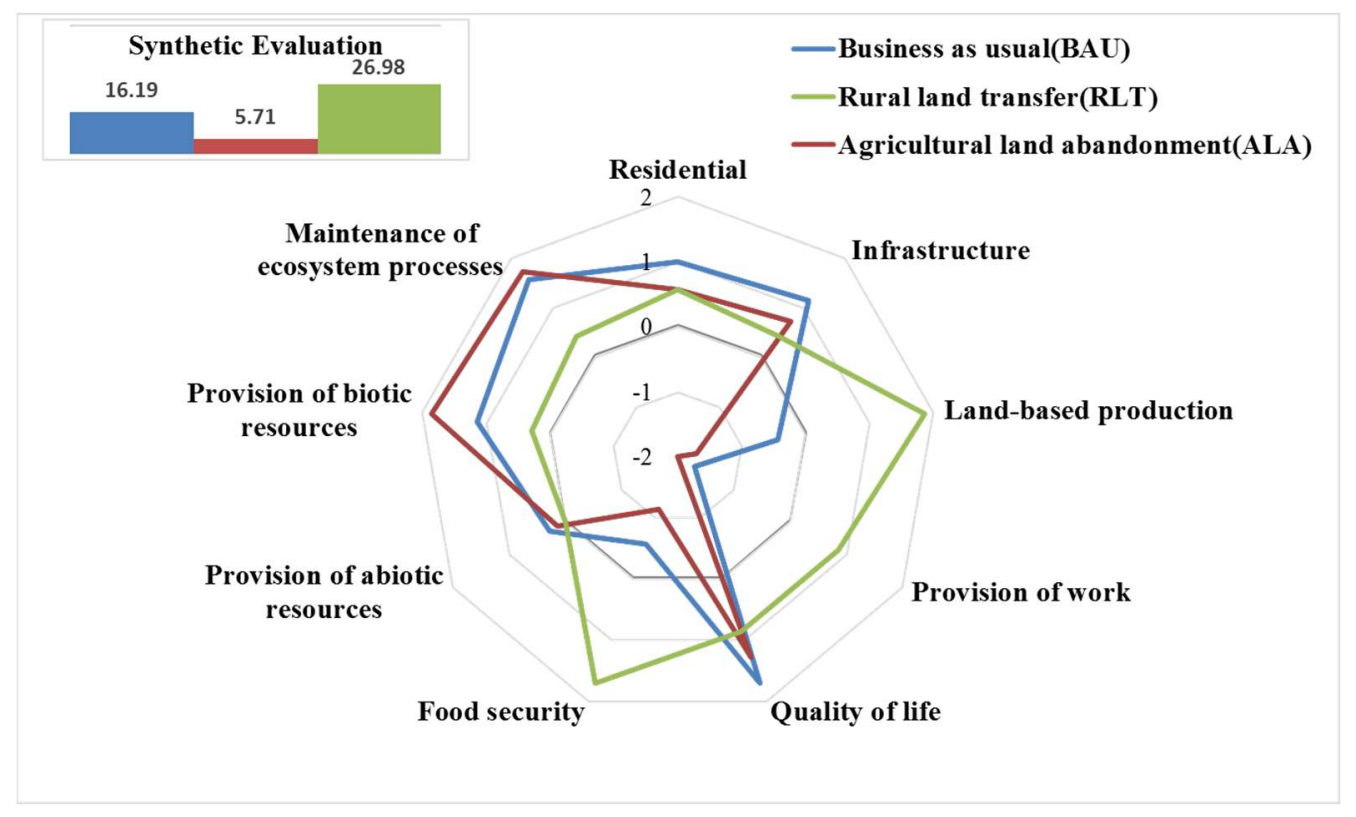

Figure 5. Impacts of the three scenarios on the land use functions (predicted values in 2025).

In the social dimension, the impacts in the BAU and ALA scenarios were all negative, and the ALA scenario produced a $148.3 \%$ worse outcome than the RLT scenario. The most important reason is likely to be the trend of increasing numbers of farmers wanting to leave their village, leading to increasing amounts of land being abandoned. One driver of this trend is that the income from rural employment transfer has increased tremendously in Guyuan, from $0.64 \times 10^{9} \mathrm{CNY}$ in 2003 to $4.62 \times 10^{9} \mathrm{CNY}$ in 2015 , representing an average annual increase of $51.8 \%$ [61]. This has been a major way for farmers to earn more disposable income. The low benefits and high costs for farmers on poor-quality land provide a strong motivation to work less in agriculture or even abandon their land. Another driver is the increasing value attributed to education. In Guyuan, 67 middle schools were all built in the region's city centers [48]. To attain a good education, parents tended to move to cities to accompany their children and also get a temporary job. With less strength in agricultural work and more abandonment of their land, the importance of the provision of work function would weaken and food security would be threatened. However, in the RLT scenario, farmers would be willing to continue working on their land, because with the help of machines, the work would become easier, they could finish the work faster, and they could double their income from renting the land and wages. This is profit for provision of work function and could ensure or even improve the quality of life and food security functions.

In the ecological dimension, the BAU and ALA scenarios would benefit from the environmental protection projects and natural recovery that occurs after abandonment of land under these scenarios, which is why they had higher positive impacts than in the RLT scenario. Since 2000, the SLCP has 
increased the regional forest cover from $35 \%$ to $73 \%$, and has increased the regional grassland cover from $12.8 \%$ to $22.2 \%$, for a total increase of $3.11 \times 10^{5}$ ha in the whole Guyuan. The trees and grasses planted during this program will gradually mature and enhance the provision of biotic resources and maintenance of ecosystem processes LUFs [62]. At the same time, the abandonment of land in the ALA scenario will permit natural recovery of the ecosystem, which would promote the maintenance of ecosystem processes LUF $[63,64]$. In addition, some of the experts expressed uncertainty about the impact of RLT owing to the homogenization, i.e., to cultivate a single kind of plant in a large scale, which might not good for the maintenance of ecosystem processes. However, some of the experts were optimistic about the balance between economic development and the short-term use of single plant types, since they argued that this approach is ecologically beneficial because it makes better use of the land than abandoned farmland [65].

Although the experts affirmed the positive synthetic impact of the RLT scenario on regional sustainable development, they also emphasized the provision of employment function. Some believed that although farmers can continue to work on their own land, but with the improvements permitted by mechanized farming, the requirement for human labor would be limited [66]. National statistics show that both the area of cultivated land and the area of land harvested by machines increased by four percent and nine percent annually, respectively, from 1990 to 2012 [67]. That is, fewer workers can produce more food because of the increased productivity. Therefore, this trend does not provide employment compared with the period dominated by individual farming with a heavy reliance on manual labor. Others believed that direct employment provided by the land is generally decreasing, but that the dependence of farmers on this LUF is also decreasing owing to the transfer to other forms of employment. According to our household survey in the five villages, $32.6 \%$ of family members had an off-farm job, and this proportion was increasing. Thus, the existing provision of employment LUF appears able to meet the current employment needs of farmers.

\subsection{Stakeholder Perceptions of RLT and Comparison with Expert Assessments}

Details of the assessments of the RLT program's impacts on the LUFs varied among the five villages owing to the different landforms and local conditions (Figure $6 \mathrm{~b}-\mathrm{f}$ ).

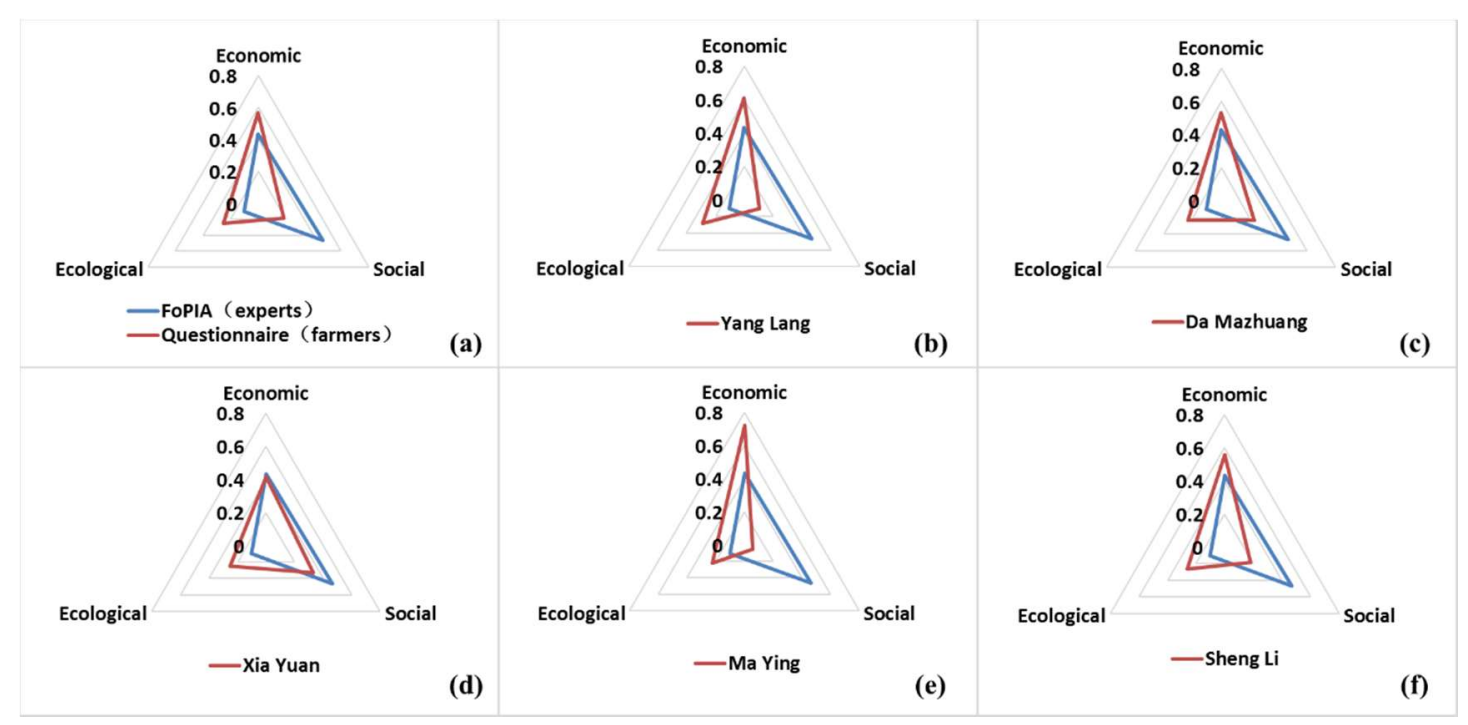

Figure 6. Comparison of the perceptions of the rural land transfer impacts between experts and farmers.

Ma Ying village (Figure 6e) had the maximum weight (0.72) in the economic dimension because it is located in a hilly area, so that most of the cultivated land is in steep slope or far from the farmers' homes; as a result, farmers here engaged more on lands while gain little benefit. For example, 
the average maize yield was $1500 \mathrm{~kg} / \mathrm{ha}$, which is $27.4 \%$ of the average yield ( $5467.48 \mathrm{~kg} / \mathrm{ha}$ ) for Guyuan as a whole in 2015 [48]. Thus, the economic functions that the land provides so they can meet the basic needs for life are the primary dimension.

Xia Yuan village (Figure $6 \mathrm{~d}$ ) had the largest proportion of impacts for the social dimension (0.33). This can be explained by the fact that the tableland in this village is much easier to manage than hilly land; as a result, $93.8 \%$ of the farmers preferred to plant the tableland by themselves, and $59.4 \%$ of the households choose to work simultaneously in town according to our survey. Considering the off-farm jobs that helped the villagers to meet their economic needs, the tableland was preferred to provide the food security LUF and to ensure the quality of life, both of which belong to the social dimension.

Da Mazhuang village (Figure 6c) reflected the high impact of the RLT on both the economic (0.53) and the social (0.23) dimensions. This can be explained by two typical phenomena in this suburban village. First, due to the short distance from the village to the nearest city (around $8 \mathrm{~km}$ ), farmers were used to working in the city and cared more about the economic function when they transferred land. In our survey, $76.7 \%$ of the households had part-time jobs in the city, and $67.4 \%$ received most of their income from off-farm work. As a result, they relied less on the land, even though the income and production from the land remained fundamental elements of their livelihood. Second, our key informant interview revealed 400 households in Da Mazhuang, but more than 120 of these families had moved into cities temporarily. The main reason was that they worked in the city, so they could accompany their children to school, but they will return to their village and work on the land after their children graduate from high school. Therefore, they considered their land as the final insurance for their work and livelihood, and they paid more attention to the social functions of the land.

In Yang Lang village (Figure 6b), with relatively good economic conditions, villagers also considered the ecological impacts of land transfers. The majority of the farmers thought that the RLT program had improved the land quality and ecological function.

In Sheng Li village (Figure $6 \mathrm{f}$ ), which had the lowest land quantity because it was mainly located on stony mountainous land, the villagers cared less about the RLT, but believed that if the government promoted the RLT, they would think highly of the ecological LUFs because of their relatively good environmental experience due to a long period of planting trees under the SLCP and tree nurseries for trade.

The experts in the FoPIA (Figure 6a) assigned the highest weight to the social dimension, with a total impact score of 0.47 , which was nearly five times the value $(0.10)$ they assigned to the ecological dimension and slightly higher than the value (0.43) they assigned to the economic dimension. However, the rates reflected in the farmer questionnaires were quite different: the farmers assigned the dimension rankings in the following order: economic $(0.57)>$ ecological $(0.25)>$ social $(0.18)$. Therefore, there were two obvious differences between the experts and the farmers: the experts gave more than twice the weight assigned by farmers to the social dimension, whereas the farmers gave more than twice the weight experts assigned to the ecological dimension.

This may be because experts had more of a regional than local perspective, and therefore believed that the RLT program could solve the problem of land abandonment and improve the food security LUF. For example, Yang Lang village is a typical successful test site, since the transferred cultivated land, which used to suffer from frequent drought, has been turned into irrigated land. As a result, the yield of potatoes from these lands increased from around $5247.38 \mathrm{~kg} / \mathrm{ha}$ to $14,992.50 \mathrm{~kg} / \mathrm{ha}$, an increase of $185.7 \%$. It is also possibly because that the farmers emphasized the ecological dimension based on their experiences. For example, Sheng Li village assigned the highest rate of the five villages to the ecological dimension in the RLT scenario (0.26). This village has been planting trees for 15 years under the SLCP and has developed tree nurseries for more than 10 years. As a result, farmers experienced visible improvement of their environment, and $62.9 \%$ of the farmers expressed the belief that owing to the afforestation, the number of animals and plants had increased. In addition, due to the implementation of irrigation and land restoration under the RLT program, the land's ability to maintain ecosystem processes was much greater, especially when compared with the land that was 
about to be abandoned. The quality of 160.33 ha of cultivated land had improved from "bad" or "medium" to "good" according to the questionnaire results for Yang Lang village, which accounts for $33.3 \%$ of the total land in the village.

We identified three issues related to implementation of the RLT program. First, not all of the farmers were willing to practice RLT. In Sheng Li village, for example, the average land area cultivated by a household was only 0.44 ha, and they preferred to develop tree nurseries, as this consumed less time and energy. Thus, the RLT is kind of meaningless for them. Second, not all of the agricultural land could be transferred. For example, in Ma Ying village, $84.0 \%$ of the farmers favored the RLT, and their willingness to transfer related strongly to the rent. However, because they mostly had access to inferior quality hilly land, few companies or households wanted to rent their land, and the rent they would have received was low. Third, with relatively good quality tableland, farmers preferred to plant by themselves using machines, without disturbing their urban employment, and they were able to consume their own organic cereals, thereby making good use of the land's ability to improve their quality of life.

\section{Conclusions}

By applying appropriate approaches to identify the opinions of three distinct groups of stakeholders and take advantage of expertise from many economic, social, and ecological disciplines, we developed an assessment framework that revealed the impact of the RLT program on LUFs in Guyuan. We reached three main conclusions:

First, the multi-level stakeholder assessment framework based on LUFs proved to be very useful for comprehensively assessing the impact of land use measures on local sustainable development and to support regional land use decisions. This framework integrates the opinions of all stakeholders to make the results more rational and comprehensive. Using the Guyuan case study, we demonstrated the positive impacts of the RLT program on regional sustainable development while also simultaneously revealing problems with and insights into the implementation of land use measures. Thus, our framework can support the identification of region-specific land use problems and the causal relationships between land use measures and the selected sustainability indicators. In future research, this method could be improved by consulting all stakeholders, not just the experts, to identify the key LUFs and take in vital indicators. Although the nine LUFs and nine indicators used in the present analysis appear satisfactory, and represent a simple and efficient approach to analyzing the key issues, it is likely that a broader consultation would reveal more factors that should be accounted for some of the nine LUFs and indicators that are also more important to farmers (e.g., including irrigation into the key infrastructure component, rather than only transportation network).

Second, compared with the BAU and ALA scenarios, the RLT scenario has the most positive synthetic impact on regional sustainable development. This is especially true for the improvement of the land's economic and social dimensions. Furthermore, the RLT scenario could dramatically benefit the land-based production and food security LUFs, with these two functions showing negative trends under the BAU and ALA scenarios that could be changed to positive trends under the RLT scenario. However, it is also possible that the government should encourage different scenarios in different areas. For example, agricultural intensification may not be an option in the stony mountain areas, particularly if irrigation is not available. In that case, ALA supported by increased implementation of the SLCP may be the most suitable approach.

Third, implementation of the RLT program should be adjusted to account for differences in local conditions to take better advantage of the multiple LUFs provided by the land and to overcome the difficulties imposed by the different landforms and location conditions. For example, for cultivated land in hilly regions, with poor conditions, farmers might be unable to find anyone to rent their land, so the most important measure might be to promote RLT by improving infrastructure (e.g., roads and irrigation) to improve the land's quality. Thus, for each region, specific measures should be carefully designed to account for that region's needs and constraints. 
Supplementary Materials: The following is available online at http:/ /www.mdpi.com/2071-1050/10/5/1376/s1, Table S1: Participants in FoPIA, Guyuan, China.

Author Contributions: Lin Zhen conceived and designed the methods and framework. Zhichao Xue performed and adjusted the implementation, analyzed the data and wrote the manuscript. Lin Zhen contributed to the interpretation of the data, discussion of results and writing of the manuscript. Both authors have read and approved the final manuscript.

Acknowledgments: This research was funded by the project "The methodology and indicator system for assessing ecological restoration technology and evaluation of global ecosystem rehabilitation technology" (grant number: 2016YFC0503700), which is supported by the National Key Research and Development (R\&D) Program of China. We also thank the program "Assessing land use functions for sustainable land management in Asia countries" (CRRP2016-04MY-Zhen) funded by the Asia-Pacific Network for Global Change Research.

Conflicts of Interest: The authors declare no conflict of interest.

\section{References}

1. Smyth, A.J.; Dumanski, J.; Spendjian, G.; Swift, M.J.; Thornton, P.K. FESLM: An International Framework for Evaluating Sustainable Land Management; Food and Agriculture Organization of the United Nations: Rome, Italy, 1993; ISBN 92-5-103419-2.

2. Bryan, B.A.; Nolan, M.; Mckellar, L.; Connor, J.D.; Newth, D.; Harwood, T.; King, D.; Navarro, J.; Cai, Y.; Gao, L. Land-use and sustainability under intersecting global change and domestic policy scenarios: Trajectories for Australia to 2050. Glob. Environ. Chang. 2016, 38, 130-152. [CrossRef]

3. Zhang, F.; Tiyip, T.; Feng, Z.D.; Kung, H.T.; Johnson, V.C.; Ding, J.L.; Tashpolat, N.; Sawut, M.; Gui, D.W. Spatio-temporal patterns of land use/cover changes over the past 20 years in the middle reaches of the tarim river, Xinjiang, China. Land Degrad. Dev. 2015, 26, 284-299. [CrossRef]

4. Euliss, N.H.J.; Smith, L.M.; Liu, S.; Feng, M.; Mushet, D.M.; Auch, R.F.; Loveland, T.R. The need for simultaneous evaluation of ecosystem services and land use change. Environ. Sci. Technol. 2010, 44, 7761-7763. [CrossRef] [PubMed]

5. Röckstrom, J.; Steffen, W.; Noone, K.; Persson, Å.; Chapin, F.S.I.; Lambin, E.F.; Lenton, T.M.; Scheffer, M.; Folke, C.; Schellnhuber, H.J.; et al. A safe operating space for humanity. Nature 2009, 461, 472-475. [CrossRef] [PubMed]

6. Arunyawat, S.; Shrestha, R.P. Assessing land use change and its impact on ecosystem services in northern Thailand. Sustainability 2016, 8, 768. [CrossRef]

7. Jin, J.; Zhang, H.; Zhou, Y. Intensive land use pattern under ecological constraints: A case study of the Dianchi lake basin. In Proceedings of the 2015 23rd International Conference on Geoinformatics, Wuhan, China, 19-21 June 2015; pp. 1-8.

8. Zhen, L.; Yan, H.; Hu, Y.; Xue, Z.; Xiao, Y.; Xie, G.; Ma, J.; Wang, J. Overview of ecological restoration technologies and evaluation systems. J. Resour. Ecol. 2017, 8, 315-324. [CrossRef]

9. FAO. The State of the World's Land and Water Resources for Food and Agriculture (SOLAW)—Managing Systems at Risk; Food and Agriculture Organization of the United Nations: Rome, Italy; Earthscan: London, UK, 2011; ISBN 978-92-5-106614-0.

10. Liniger, H.; Studer, R.M.; Moll, P.; Zander, U. Making Sense of Research for Sustainable Land Management; Centre for Development and Environment (CDE), University of Bern, Switzerland and Helmholtz-Centre for Environmental Research GmbH-UFZ: Leipzig, Germany, 2017; ISBN 978-3-944280-99-8.

11. Orr, B.J.; Cowie, A.L.; Sanchez, V.M.C.; Chasek, P.; Crossman, N.D.; Erlewein, A.; Louwagie, G.; Maron, M.; Metternicht, G.I.; Minelli, S. Scientific Cconceptual Framework for Land Degradation Neutrality; United Nations Convention to Combat Desertitication (UNCCD): Bonn, Germany, 2017; ISBN 978-92-95110-59-5.

12. United Nations Development Programme (UNDP). 2015 UNDP in Focus 2014/2015-Time for Global Action; UNDP: New York, NY, USA, 2015.

13. European Commission. A strategic approach to EU agricultural research \& innovation (final paper). In Designing the Path, a Strategic Approach to EU Agricultural Research and Innovation; Agriculture and Rural Development of European Commission: Brussels, Belgium, 2016.

14. United Nations. The Sustainable Development Goals Report 2017; United Nations: New York, NY, USA, 2017; ISBN 978-92-1-361715-1. 
15. UNCCD. Report of the Conference of the Parties on Its Twelfth Session, Held in Ankara from 12 to 23 Octorber 2015. Part Two: Actions Taken by the Conference of the Parties at Its Twelfth Session; United Nations Convention to Combat Desertification: Bonn, Germany, 2015.

16. Fürst, C.; Helming, K.; Lorz, C.; Müller, F.; Verburg, P.H. Integrated land use and regional resource management-A cross-disciplinary dialogue on future perspectives for a sustainable development of regional resources. J. Environ. Manag. 2013, 127, S1-S5. [CrossRef] [PubMed]

17. Global Land Project (GLP). Science Plan and Implementation Strategy; IGBP Report No. 53/IHDP Report No. 19; IGBP Secretariat: Stockholm, Sweden, 2005.

18. Pérez-Soba, M.; Petit, S.; Jones, L.; Bertrand, N.; Briquel, V.; Omodei-Zorini, L.; Contini, C.; Helming, K.; Farrington, J.H.; Mossello, M.T. Land use functions-A multifunctionality approach to assess the impact of land use changes on land use sustainability. In Sustainability Impact Assessment of Land Use Changes; Springer: Berlin, Germany, 2008; pp. 375-404, ISBN 978-3-540-78647-4.

19. Wiggering, H.; Müller, K.; Werner, A.; Helming, K. The concept of multifunctionality in sustainable land development. In Sustainable Development of Multifunctional Landscapes; Springer: Berlin, Germany, 2003; pp. 3-18, ISBN 978-3-540-78647-4.

20. König, H.J. Operationalising Sustainability Impact Assessment of Land Use Scenarios in Developing Countries: A Stakeholder-Based Approach with Case Studies in China, India, Indonesia, Kenya, and Tunisia. Ph.D. Thesis, University of Potsdam, Potsdam, Germany, 2013.

21. Zhen, L.; Cao, S.; Wei, Y.; Xie, G.; Fen, L.I.; Yang, L. Land use functions: Conceptual framework and application for China. Resour. Sci. 2009, 31, 544-551.

22. Peng, J.; Liu, Z.; Liu, Y.; Hu, X.; Wang, A. Multifunctionality assessment of urban agriculture in Beijing city, China. Sci. Total Environ. 2015, 537, 343-351. [CrossRef] [PubMed]

23. Wei, Y.J. Multifunctionality of land use in Jinghe region of northwestern China. Master's Thesis, Graduate University of Chinese Academy of Sciences, Beijing, China, 2010.

24. Zhou, D.; Xu, J.; Lin, Z. Conflict or coordination? Assessing land use multi-functionalization using production-living-ecology analysis. Sci. Total Environ. 2017, 577, 136-147. [CrossRef] [PubMed]

25. König, H.J.; Podhora, A.; Lin, Z.; Helming, K.; Yan, H.M.; Du, B.Z.; Wübbeke, J.; Chao, W.; Klinger, J.; Cheng, C. Knowledge brokerage for impact assessment of land use scenarios in Inner Mongolia, China: Extending and testing the FoPIA approach. Sustainability 2015, 7, 5027-5049. [CrossRef]

26. Morris, J.B.; Tassone, V.; Groot, R.D.; Camilleri, M. A framework for participatory impact assessment: Involving stakeholders in European policy making, a case study of land use change in Malta. Ecol. Soc. 2011, 16, 1-2. [CrossRef]

27. Verburg, P.H.; Crossman, N.; Ellis, E.C.; Heinimann, A.; Hostert, P.; Mertz, O.; Nagendra, H.; Sikor, T.; Erb, K.H.; Golubiewski, N. Land system science and sustainable development of the earth system: A global land project perspective. Anthropocene 2015, 12, 29-41. [CrossRef]

28. The Agricultural European Innovation Partnership. EIP-AGRI Brochure Agricultural Knowledge and Innovation Systems. Available online: https:/ / ec.europa.eu/eip/agriculture/sites/agri-eip/files/eip-agri_ brochure_knowledge_systems_2018_en_web.pdf (accessed on 27 April 2018).

29. The Agricultural European Innovation Partnership. EIP-AGRI Brochure Horizon 2020 Multi-Actor Projects. Available online: https:/ / ec.europa.eu/eip/agriculture/sites/agri-eip/files/eip-agri_brochure_ multi-actor_projects_2017_en_web.pdf (accessed on 27 April 2018).

30. Feng, Z.; Yang, Y.; Zhang, Y.; Zhang, P.; Li, Y. Grain-for-green policy and its impacts on grain supply in west China. Land Use Policy 2005, 22, 301-312. [CrossRef]

31. Zhen, L.; Du, B. Ecological footprint analysis based on changing food consumption in a poorly developed area of China. Sustainability 2017, 9, 1323. [CrossRef]

32. Liu, Y.; Yang, R.; Long, H.; Gao, J.; Wang, J. Implications of land-use change in rural China: A case study of Yucheng, Shandong province. Land Use Policy 2014, 40, 111-118. [CrossRef]

33. Zhang, Y.; Li, X.; Song, W. Determinants of cropland abandonment at the parcel, household and village levels in mountain areas of China: A multi-level analysis. Land Use Policy 2014, 41, 186-192. [CrossRef]

34. Gan, L.; Yin, Z.; Tan, J. China Household Finance Survey Report 2014; Southwestern University of Finance and Economics Press: Chengdu, China, 2015; ISBN 9787550418097.

35. Gu, S.; Wang, X.; Lu, J.; Wang, Y.; Zhang, X. Land moving mode in rural areas, its domino effect and innovation. Chin. J. Agric. Resour. Reg. Plan. 2009, 30, 1-8. [CrossRef] 
36. Saquina Mucavele, M. The Role of Rural Women in Agriculture. Available online: http:/ /www.wfo-oma.org/ women-in-agriculture/articles/the-role-of-rural-women-in-agriculture.html (accessed on 27 April 2018).

37. Ajadi, A.A.; Oladele, O.I.; Ikegami, K.; Tsuruta, T. Rural women's farmers access to productive resources: The moderating effect of culture among Nupe and Yoruba in Nigeria. Agric. Food Secur. 2015, 4, 26. [CrossRef]

38. Zhao, Y. Leaving the countryside: Rural-to-urban migration decisions in China. Am. Econ. Rev. 1999, 89, 281-286. [CrossRef]

39. Du, Y.; Sun, B. The development of Chinese agricultural land transfer system: Transaction, concentration and commercialization. J. Agric. Sci. 2011, 3, 269-274. [CrossRef]

40. Wu, H.; Miao, Y.; Jiang, H.; Xu, D.; Jiao, W. Improving the circulation market of land contractual management rights for land operation with proper scale-up. Chin. Agric. Sci. Bull. 2008, 24, 547-550.

41. State Council of the People's Republic of China. Notice of the State Council Approved the Suggestions about Stabilize and Improve Land Contract Relations by Ministry of Agriculture; State Council of the People's Republic of China: Beijing, China, 1995.

42. Ministry of Agriculture of the People's Republic of China. Management Measures for the Transfer of Rural Land Contractual Management Right; No. 47; Ministry of Agriculture of the People's Republic of China: Beijing, China, 2005.

43. Organization for Economic Co-operation and Development (OECD). OECD Core Set of Indicators for Environmental Performance Reviews; Organization for Economic Co-operation and Development: Paris, France, 1993.

44. Purushothaman, S.; Patil, S.; Francis, I.; König, H.J.; Reidsma, P.; Hegde, S. Participatory impact assessment of agricultural practices using the land use functions framework: Case study from India. Int. J. Biodivers. Sci. Ecosyst. Serv. Manag. 2013, 9, 2-12. [CrossRef]

45. Schindler, J.; Graef, F.; König, H.J. Methods to assess farming sustainability in developing countries. A review. Agron. Sustain. Dev. 2015, 35, 1043-1057. [CrossRef]

46. König, H.J.; Zhen, L.; Helming, K.; Uthes, S.; Yang, L.; Cao, X.; Wiggering, H. Assessing the impact of the sloping land conversion programme on rural sustainability in Guyuan, western China. Land Degrad. Dev. 2014, 25, 385-396. [CrossRef]

47. Wang, C.; Zhen, L. A comparative assessment of land use functions based on perceptions of policy makers and local farmers in Guyuan, western China. J. Resour. Ecol. 2017, 8, 232-241. [CrossRef]

48. Guyuan Bureau of Statistics. 2015 Handbook of Socio-Economic Development Statistics in Guyuan; Guyuan Bureau of Statistics: Guyuan, China, 2016.

49. Guyuan Bureau of Statistics. 2015 Statistical Communiqu for National Economic and Social Development in Guyuan; Guyuan Bureau of Statistics: Guyuan, China, 2016.

50. Guyuan Bureau of Forestry. Report on Sloping Land Conversion Programme Implementation in Guyuan; Guyuan Bureau of Forestry: Guyuan, China, 2015.

51. Scherr, S.J.; Yadav, S. Land degradation in the developing world: Implications for food, agriculture, and the environment to 2020. In Vision Discussion Papers; International Food Policy Research Institute: Washington, DC, USA, 1996.

52. Holden, S.; Shiferaw, B. Land degradation, drought and food security in a less-favoured area in the Ethiopian highlands: A bio-economic model with market imperfections. Agric. Econ. 2004, 30, 31-49. [CrossRef]

53. Zhen, L.; Cao, S.Y.; Cheng, S.K.; Xie, G.D.; Wei, Y.J.; Liu, X.L.; Li, F. Arable land requirements based on food consumption patterns: Case study in rural Guyuan district, western China. Ecol. Econ. 2010, 69, 1443-1453. [CrossRef]

54. Jiao, F.; Wen, Z.M.; Wang, F.; Zhang, X.P.; Yang, Q.K.; Rui, L.I. Analysis of landscape structure at county scale in loess hilly region. J. Soil Water Conserv. 2005, 19, 167-170. [CrossRef]

55. Agriculture and Animal Husbandry Bureau of Guyuan. 2015 Statistic Book of Rural Land Transfer in Guyuan; Agriculture and Animal Husbandry Bureau of Guyuan: Guyuan, China, 2016.

56. Zhang, N. Landscape Ecology; Science Press: Beijing, China, 2014; ISBN 9787030406231.

57. König, H.J.; Podhora, A.; Helming, K.; Lin, Z.; Chao, W.; Wuebbeke, J.; Baumeister, T.; Du, B.; Yan, H. Confronting international research topics with stakeholders on multifunctional land use: The case of Inner Mongolia, China. Iforest Biogeosci. For. 2014, 7, 403-413. [CrossRef] 
58. Reed, M.S.; Graves, A.; Dandy, N.; Posthumus, H.; Hubacek, K.; Morris, J.; Prell, C.; Quinn, C.H.; Stringer, L.C. Who's in and why? A typology of stakeholder analysis methods for natural resource management. J. Environ. Manag. 2009, 90, 1933-1949. [CrossRef] [PubMed]

59. Ali, M.; David, M.K.; Lai, L.C. Using the Key Informants Interviews (KIIs) technique: A social sciences study with Malaysian and Pakistani respondents. Man Soc. 2013, 24, 131-148.

60. Simelton, E.; Dam, B.V. Farmers in ne viet nam rank values of ecosystems from seven land uses. Ecosyst. Serv. 2014, 9, 133-138. [CrossRef]

61. Human Resources and Social Security Bureau of Guyuan. Statistics of Labor Transfer Employment in 2016; Human Resources and Social Security Bureau of Guyuan: Guyuan, China, 2017.

62. Wang, F.; Li, R.; Jiao, F.; Yang, Q.; Tian, J. The impact of cropland conversion on environmental effect in the loess plateau: A pilot study based on the national experimental bases. J. Geogr. Sci. 2005, 15, 484-490. [CrossRef]

63. Sulieman, H.M. Natural regeneration potential of abandoned agricultural land in the southern Gadarif region, Sudan: Implications for conservation. Afr. J. Ecol. 2013, 52, 217-227. [CrossRef]

64. Zhang, C.; Liu, G.; Xue, S.; Wang, G. Changes in rhizospheric microbial community structure and function during the natural recovery of abandoned cropland on the loess plateau, China. Ecol. Eng. 2015, 75, 161-171. [CrossRef]

65. Keenleyside, C.; Tucker, G. Farmland Abandonment in the EU: An Assessment of Trends and Prospects; Institute for European Environmental Policy: London, UK, 2010.

66. Wang, X.; Yamauchi, F.; Huang, J. Rising wages, mechanization, and the substitution between capital and labor: Evidence from small scale farm system in China. Agric. Econ. 2016, 47, 309-317. [CrossRef]

67. National Statistical Bureau of China (NSBC). China Yearbook Rural Household Survey; China Statistics Press: Beijing, China; pp. 1985-2013.

(C) 2018 by the authors. Licensee MDPI, Basel, Switzerland. This article is an open access article distributed under the terms and conditions of the Creative Commons Attribution (CC BY) license (http://creativecommons.org/licenses/by/4.0/). 